\title{
PEMODELAN KOMPETISI ANTAR BAHASA PADA KOMUNITAS MONOLINGUAL DAN BILINGUAL
}

\author{
TISSA PUTRI YUNITA, MAHDHIVAN SYAFWAN \\ Program Studi Matematika, \\ Fakultas Matematika dan Ilmu Pengetahuan Alam, Universitas Andalas, \\ Kampus UNAND Limau Manis Padang, Indonesia, \\ email : putriyunita.tissa@gmail.com
}

\begin{abstract}
Abstrak. Pada makalah ini dijelaskan tentang penurunan model kompetisi antar bahasa pada komunitas monolingual dan bilingual. Model ini kemudian dibandingkan dengan data empiris penutur bahasa Gaelic di Ross and Cromarty Skotlandia untuk kasus monoli-ngual dan data empiris penutur bahasa Melayu di Brunei untuk kasus bilingual. Dari hasil pencocokan model terhadap data, diperoleh nilai-nilai parameter yang cukup kecil yang membuat proporsi penutur bahasa Gaelic dan Melayu menurun secara signifikan dari tahun ke tahun sehingga terancam mengalami kepunahan.
\end{abstract}

Kata Kunci: Model kompetisi antar bahasa, kepunahan bahasa, monolingual, bilingual, pencocokan data

\section{Pendahuluan}

Kepunahan bahasa pada saat ini telah menjadi suatu ancaman tersendiri bagi dunia internasional. Diperkirakan lebih dari 6000 bahasa yang digunakan di dunia dan diramalkan $50 \%$ diantaranya akan punah pada akhir abad ini. Upaya pencegahan kepunahan suatu bahasa perlu dilakukan, karena dengan punahnya suatu bahasa, maka semua nilai-nilai budaya yang terkandung dalam bahasa tersebut juga akan ikut punah. Dalam upaya pencegahan tersebut, sangat penting untuk mengetahui terlebih dahulu parameter-parameter yang mempengaruhi keberlangsungan bahasa yang terancam punah. Parameter-parameter tersebut secara kuantitatif dapat diperoleh dari suatu model matematika yang mendeskripsikan tingkat "persaingan" antar bahasa.

Model persaingan antar bahasa pada komunitas monolingual digagas pertama kali oleh Abrams dan Strogatz dan diterapkan pada kasus bahasa Welsh dan Scotish Gaelic di United Kingdom dan bahasa Quecha di Amerika[1. Model tersebut kemudian dikembangkan oleh Mira dan Paredes untuk kasus bilingual dan membandingkannya dengan data historis penutur bahasa Galician dan Castilian di daerah Galicia Spanyol [4].

Pada makalah ini, kedua model tersebut akan dijelaskan kembali dengan lebih mendetail dan diterapkan pada kasus bahasa yang berbeda. Sebagian besar pembahasan pada paper ini merujuk pada 9 . 


\section{Penurunan Model Kompetisi Antar Bahasa pada Komunitas Monolingual}

Pandang sistem dari dua bahasa yang saling berkompetisi, $X$ dan $Y$, dengan proporsi penutur bahasa $X$ dinotasikan dengan $x$ dan proporsi penutur bahasa $Y$ dinotasikan dengan $y$, dimana $x+y=1$.

Pada sistem ini diasumsikan beberapa hal sebagai berikut:

(1) Proporsi penutur bahasa $X$ dan $Y$ pada awalnya tidak nol dan tidak satu, yaitu $x, y \in(0,1)$.

(2) Masing - masing individu hanya mampu berkomunikasi dengan menggunakan satu bahasa (monolingual).

(3) Populasi saling terhubung kuat, dengan struktur spasial dan sosial yang seragam, atau dengan kata lain tiap-tiap individu berinteraksi pada taraf yang sama.

(4) Peralihan individu menggunakan suatu bahasa ke bahasa kompetitor, misalnya dari bahasa $X$ ke bahasa $Y$, disebabkan oleh daya tarik yang dimiliki bahasa kompetitor tersebut.

(5) Daya tarik dari suatu bahasa akan meningkat seiring dengan banyaknya penutur dan tingginya status relatif bahasa tersebut. Adapun yang dimaksud dengan status relatif suatu bahasa adalah parameter yang merefleksikan keuntungan sosial dan ekonomi yang diperoleh oleh penuturnya. Disini status relatif untuk bahasa $X$ dan $Y$ berturut-turut dinotasikan dengan $s_{X}$ dan $s_{Y}$, dengan $s_{X}+$ $s_{Y}=1$.

Misalkan seorang penutur bahasa $Y$ beralih ke bahasa $X$ dengan peluang $P_{Y X}\left(x, s_{X}\right)$ per satuan waktu. Sebaliknya, seorang penutur bahasa $X$ beralih ke bahasa $Y$ dengan peluang $P_{X Y}\left(y, s_{Y}\right)$ per satuan waktu. Dengan demikian, laju perubahan dari proporsi penutur bahasa $X$ dapat dimodelkan dengan persamaan diferensial biasa orde satu berikut :

$$
\frac{d x}{d t}=y P_{Y X}\left(x, s_{X}\right)-x P_{X Y}\left(y, s_{Y}\right) .
$$

Perhatikan bahwa kita tidak perlu menulis persamaan untuk $y$ karena $x$ dan $y$ tidak saling bebas, yaitu memenuhi hubungan $x+y=1$.

Selanjutnya berdasarkan asumsi (5), fungsi peluang $P_{Y X}\left(x, s_{X}\right)$ dan $P_{X Y}\left(y, s_{Y}\right)$ dimisalkan mengikuti distribusi power-law, yaitu [1] :

$$
\begin{aligned}
& P_{Y X}\left(x, s_{X}\right)=c s_{X} x^{a}, \text { dan } \\
& P_{X Y}\left(y, s_{Y}\right)=c s_{Y} y^{a}=c\left(1-s_{X}\right)(1-x)^{a} .
\end{aligned}
$$

dimana $a$ adalah parameter yang mendeskripsikan bagaimana daya tarik suatu bahasa diukur dari banyak penuturnya, sedangkan $c$ merefleksikan faktor sosiolinguistik yang mempengaruhi pemakaian suatu bahasa, seperti tingkat interaksi pada pasangan individu, kecenderungan mempelajari bahasa baru, atau kebijakan politik yang mengharuskan seseorang mempelajari bahasa baru.

Perumusan peluang peralihan bahasa pada persamaan 2.2 dan 2.3 menghasilkan beberapa fakta berikut : 
(1) Apabila suatu bahasa tidak memiliki penutur, maka perpindahan bahasa tersebut ke bahasa lainnya tidak akan terjadi: $P_{Y X}\left(0, s_{X}\right)=P_{X Y}\left(0, s_{Y}\right)=0$.

(2) Tidak ada seorangpun yang akan mengadopsi bahasa yang tidak memiliki status relatif, artinya tidak ada keuntungan sosial dan ekonomi ketika menggunakan bahasa tersebut: $P_{Y X}(x, 0)=P_{X Y}(y, 0)=0$.

(3) Dengan sifat kesimetrian, peralihan bahasa mestilah sama ketika dipertukarkan proporsi penutur dan status relatifnya: $P_{Y X}\left(y, s_{Y}\right)=P_{X Y}\left(y, s_{Y}\right)$.

Dari persamaan (2.2) dan (2.3), persamaan (2.1) dapat ditulis kembali sebagai

$$
\frac{d x}{d t}=c(1-x) s_{X} x^{a}-c x\left(1-s_{X}\right)(1-x)^{a} .
$$

Selanjutnya akan ditentukan titik kesetimbangan dari persamaan (2.4), yaitu ketika proporsi penutur bahasa $X$ tidak lagi mengalami perubahan (konstan). Hal ini dapat dicari dengan menetapkan $\frac{d x}{d t}=0$. Dari persamaan tersebut diperoleh tiga titik kesetimbangan berikut:

(i) $x=0$, yang berarti tidak ada lagi yang menggunakan bahasa $X$ (terjadi kepunahan bahasa $X$ ).

(ii) $x=1$, yang berarti tidak ada lagi yang menggunakan bahasa $Y$ (terjadi kepunahan bahasa $Y)$.

(iii) $s_{X}=\operatorname{frac}(1-x)^{a-1} x^{a-1}+(1-x)^{a-1}$ untuk $x \in(0,1)$, yang berarti nilai $s_{X}$ selalu dapat dicari untuk setiap $x \in(0,1)$, sehingga memungkinkan suatu daerah memakai dua bahasa yang berbeda sekaligus yang dapat dikontrol dari status relatif bahasa tersebut berdasarkan proporsi penutur masing-masing bahasa.

Model (2.4) juga dapat bertindak sebagai sistem "peringatan" kepada suatu komunitas masyarakat tentang ancaman kepunahan bahasa asli mereka, sehingga langkah - langkah yang tepat untuk mencegah hal tersebut terjadi dapat dilakukan sejak dini. Untuk mengetahui hal ini, persamaan 2.4 harus diselesaikan secara analitik atau numerik, kemudian solusi yang diperoleh dicocokkan dengan data empiris.

\section{Penurunan Model Kompetisi Antar Bahasa pada Komunitas Bilingual}

Pada model sebelumnya, kelompok individu yang menggunakan dua bahasa (bilingual) diabaikan, padahal dalam kenyataannya fenomena ini se-ring dijumpai dalam komunitas masyarakat. Oleh karena itu pada subbab ini model (2.4) akan dimodifikasi dengan menambahkan suatu parameter yang mendeskripsikan kemiripan dua bahasa yang saling berkompetisi.

Pada model bilingual ini, diperkenalkan kelompok bahasa bilingual yang dinotasikan dengan $B$, dimana proporsi penuturnya adalah $b$ dan status relatifnya adalah $s_{B}$, dengan $x+y+b=1$ dan $s_{B}=k s_{Y}$ (nilai $k$ akan dijelaskan kemudian). Proporsi individu yang menggunakan bahasa $X$ dapat dimodelkan dengan :

$$
\frac{d x}{d t}=y P_{Y X}\left(x, s_{X}\right)+b P_{B X}\left(x, s_{X}\right)-x\left(P_{X Y}\left(y, s_{Y}\right)+P_{X B}\left(b, s_{B}\right)\right) .
$$


Peluang peralihan bahasa $X$ ke $B$ dan $X$ ke $Y$ diberikan berturut-turut oleh

$$
\begin{aligned}
& P_{X B}\left(b, s_{B}\right)=c s_{B} b^{a}=c k s_{Y}(1-x)^{a}, \text { dan } \\
& P_{X Y}\left(y, s_{Y}\right)=c s_{Y} y^{a}=c(1-k) s_{Y}(1-x)^{a},
\end{aligned}
$$

dimana $k(0 \leq k \leq 1)$ merupakan parameter yang menggambarkan "kemudahan" bilingualisme, atau dengan kata lain merefleksikan kemiripan dari dua bahasa $X$ dan $Y$. Nilai $k=0$ berarti tidak terdapat kemiripan sama sekali antara bahasa $X$ dan $Y$, sehingga tidak mungkin terjadi komunikasi antar penutur bahasa $X$ dengan penutur bahasa $Y$. Jadi untuk kasus ini $(k=0)$ berlaku $P_{X B}=0$. Sebaliknya, nilai $k=1$ mengakibatkan $X=Y$ sehingga $P_{X Y}=0$ dan $P_{X B}$ menjadi sama dengan $P_{X Y}$ pada model monolingual 2.4.

Selanjutnya peluang peralihan bahasa $Y$ ke $B$ dan $Y$ ke $X$ berturut-turut diberikan oleh

$$
\begin{aligned}
P_{Y B}\left(b, s_{B}\right) & =c s_{B} b^{a}=c k s_{Y}(1-y)^{a}, \text { dan } \\
P_{Y X}\left(x, s_{X}\right) & =c s_{X} x^{a}=c(1-k) s_{X}(1-y)^{a} .
\end{aligned}
$$

Peralihan dari $B$ ke $X$ dan dari $Y$ ke $X$ sama-sama menyebabkan berkurangnya proporsi penutur bahasa $Y$ yang disebabkan terutama karena faktor kematian. Dengan demikian dapat diasumsikan bahwa $P_{B X}=P_{Y X}$. Dengan cara yang sama diperoleh juga $P_{B Y}=P_{X Y}$.

Dengan demikian, kompetisi dua bahasa pada kasus bilingual dimodelkan oleh sistem dua persamaan diferensial terikat berikut :

$$
\begin{aligned}
& \frac{d x}{d t}=c\left[(1-x)(1-k) s_{X}(1-y)^{a}-x\left(\left(1-s_{X}\right)(1-x)^{a}\right)\right], \\
& \frac{d y}{d t}=c\left[(1-y)(1-k)\left(1-s_{X}\right)(1-x)^{a}-y s_{X}(1-y)^{a}\right] .
\end{aligned}
$$

Disini persamaan untuk $b$ tidak perlu dituliskan karena nilai $b$ dapat ditentukan melalui hubungan $x+y+b=1$.

\section{Perbandingan Model dengan Data Empiris}

Model Kompetisi antar bahasa yang telah dirumuskan pada bagian sebelumnya akan dibandingkan dengan data empiris, baik pada kasus komunitas monolingual maupun bilingual.

\subsection{Komunitas Monolingual}

Data yang digunakan untuk membandingkan model kompetisi bahasa pada komunitas monolingual pada subbab ini adalah proporsi penutur bahasa Gaelic di daerah Ross and Cromarty Skotlandia [8]. Selanjutnya lakukan pencocokan model 2.4 terhadap data di atas dengan menggunakan optimasi numerik untuk parameter. Untuk mengukur kecocokan model dengan data, ditentukan koefisien determinasinya, yaitu $R^{2}=0,9884$, yang menunjukkan kesesuaian yang sangat baik antara model dan data. Hasil pencocokan data tersebut diperlihatkan pada Gambar 1.

Dari hasil pencocokan data diperoleh nilai - nilai parameter sebagai berikut: 


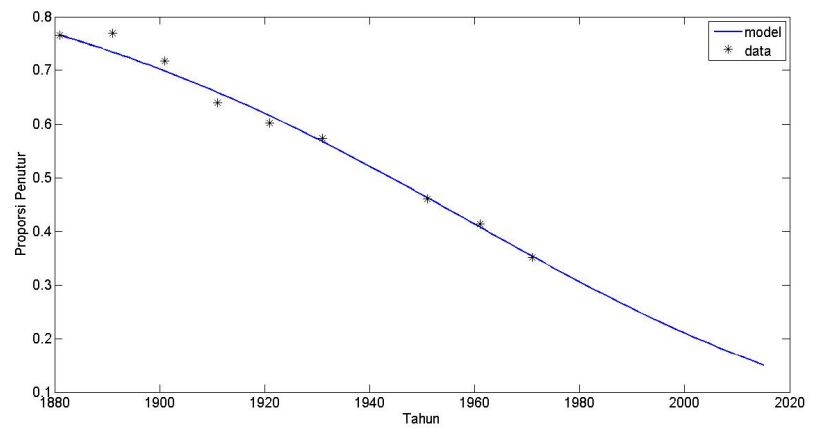

Gambar 1. Hasil Pencocokan Model dengan Data Proporsi Penutur Bahasa Gaelic

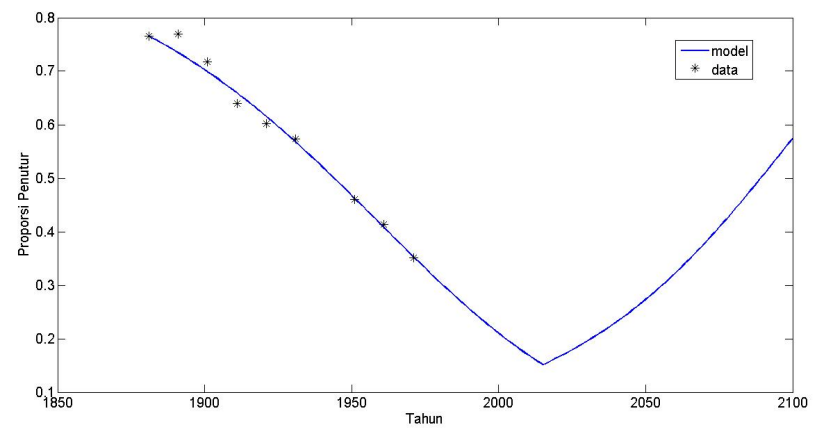

Gambar 2. Peningkatan Proporsi Penutur Bahasa Gaelic ketika Status Relatif (s)=0,5582

(1) Nilai ketertarikan bahasa Gaelic $(a)$.

Pada kasus ini, nilai ketertarikan dari bahasa Gaelic adalah sebesar 1,0974.

Hasil ini menunjukkan bahwa bahasa Gaelic mempunyai daya tarik yang relatif tetap dari tahun ke tahun (proporsional dengan jumlah penuturnya).

(2) Status relatif bahasa Gaelic $(s)$.

Nilai parameter yang merepresentasikan status relatif dari bahasa Gaelic adalah sebesar 0,2582. Hal ini menunjukkan bahwa tingkat keuntungan sosial maupun ekonomi yang diperoleh oleh penutur bahasa Gaelic dinilai cukup rendah.

(3) Faktor sosiolinguistik (c).

Nilai faktor sosiolinguistik yang diperoleh untuk bahasa Gaelic adalah sebesar 0,0367, yang menunjukkan nilai yang cukup kecil.

Dari Gambar 1 dapat dilihat bahwa proporsi penutur bahasa Gaelic diperkirakan terus menurun dan terancam mengalami kepunahan. Hal ini disebabkan oleh rendahnya nilai parameter-parameter yang mempengaruhi bahasa tersebut.

Untuk mencegah terjadinya kepunahan bahasa Gaelic, maka perlu dilakukan beberapa langkah strategis agar dapat meningkatkan nilai-nilai parameter yang 
disebutkan di atas, seperti mewajibkan pelajaran bahasa Gaelic di sekolah-sekolah, kampenye pelestarian bahasa Gaelic, dan lain-lain. Sebagai contoh ilustrasi, jika langkah-langkah strategis tersebut mampu meningkatkan status relatif bahasa Gaelic menjadi 0,5582, maka jumlah penutur bahasa Gaelic akan mengalami peningkatan, sebagaimana yang diperlihatkan pada Gambar 2, sehingga ancaman kepunahan bahasa Gaelic akan dapat dihindari.

\subsection{Komunitas Bilingual}

Untuk komunitas bilingual, data yang akan digunakan untuk membandingkan model adalah proporsi penutur bahasa Melayu dan bahasa Inggris di Brunei. Selanjutnya dari data tersebut dilakukan pencocokan terhadap model (3.6) dan (3.7) dengan menggunakan optimasi numerik untuk parameter persamaan diferensial.Untuk mengukur kecocokan model dengan data, ditentukan koefisien determinasinya, yaitu $R_{M}{ }^{2}=0,9283$ untuk proporsi penutur bahasa Melayu, ${R_{I}}^{2}=0,5890$ untuk proporsi bahasa Inggris, dan $R_{B}{ }^{2}=0,8689$ untuk proporsi penutur bilingual bahasa Melayu dan Inggris. Kecuali untuk proporsi penutur bahasa Inggris, nilai-nilai koefisien determinasi ini menunjukkan kesesuaian yang cukup baik antara model dan data. Hasil pencocokan data tersebut diperlihatkan pada Gambar 3.

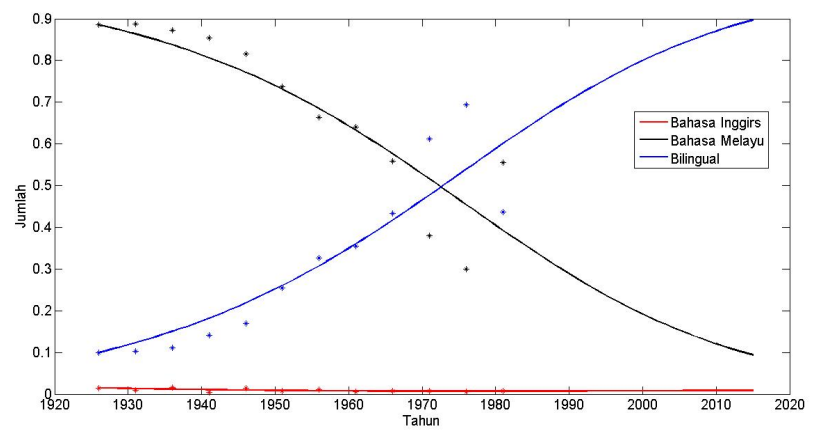

Gambar 3. Hasil Pencocokan Model dengan Data Proporsi Penutur Bahasa Melayu, Inggris, dan Bilingual di Brunei. Solusi model ditunjukkan oleh garis, sedangkan data ditunjukkan oleh tanda *.

Nilai - nilai parameter yang diperoleh dari hasil pencocokan data tersebut adalah sebagai berikut:

(1) Nilai ketertarikan bahasa Melayu $(a)$.

Pada kasus ini, nilai ketertarikan bahasa Melayu diperoleh sebesar 1,0845. Hal ini menunjukkan bahwa bahasa Melayu mempunyai daya tarik yang relatif tetap (proporsional dengan jumlah penuturnya).

(2) Status bahasa relatif $(s)$.

Nilai parameter yang menjelaskan status relatif bahasa Melayu adalah sebesar 0,2546. Hasil ini menunjukkan bahwa tingkat keuntungan sosial maupun 
ekonomi yang diperoleh oleh penutur bahasa Melayu cukup kecil.

(3) Faktor sosiolinguistik (c).

Faktor sosiolingustik yang diperoleh untuk bahasa Melayu menunjukkan nilai yang cukup kecil, yaitu sebesar 0,1062 .

(4) Kemiripan bahasa Melayu dan Inggrris $(k)$.

Nilai parameter yang mendeskripsikan tingkat kemiripan antara bahasa Melayu dan bahasa Inggris adalah sebesar 0,9955. Hal ini menunjukkan bahwa terdapat kemiripan yang sangat tinggi pada kedua bahasa tersebut.

Dari Gambar 3 juga dapat dilihat bahwa proporsi penutur bahasa Melayu dan penutur bahasa Inggris di Brunei cenderung menurun dari tahun ke tahun, dengan laju penurunan yang sangat tinggi terjadi pada penutur bahasa Melayu. Hal ini disebabkan oleh rendahnya nilai parameter-parameter yang mempengaruhi bahasa tersebut. Di lain pihak, proporsi penutur yang menggunakan bahasa Melayu sekaligus bahasa Inggris (bilingual) terus meningkat. Hal ini disebabkan karena tingginya tingkat kemiripan antara bahasa Melayu dan Inggris, sehingga penuturnya mendapatkan kemudahan pada saat menggunakan kedua bahasa tersebut.

Untuk mencegah terjadinya kepunahan bahasa Melayu, maka seperti yang dijelaskan pada kasus monolingual, perlu dilakukan beberapa langkah strategis untuk menigkatkan nilai- nilai parameter yang mempengaruhi bahasa tersebut. Sebagai contoh ilustrasi, jika setelah langkah-langkah tersebut dapat meningkatkan status relatif bahasa Melayu menjadi 0,5546, maka jumlah penutur bahasa Melayu akan meningkat secara perlahan, sebagaimana yang diperlihatkan pada Gambar 4. Dengan cara ini, ancaman kepunahan pada bahasa Melayu di Brunei akan dapat dihindari.

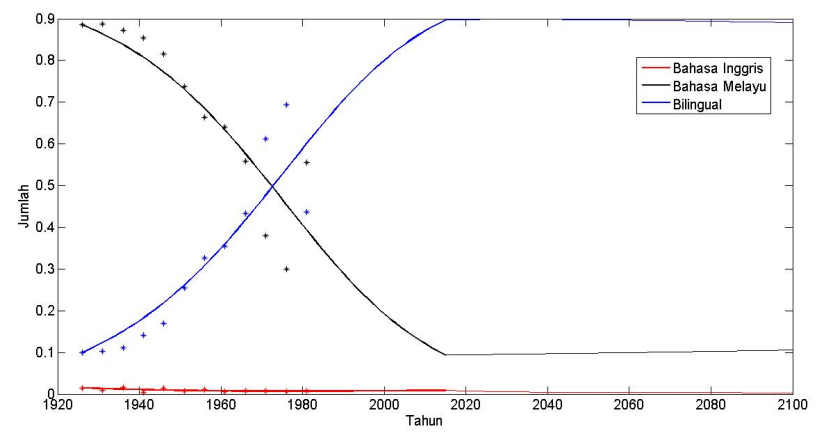

Gambar 4. Peningkatan Proporsi Penutur Bahasa Melayu di Brunei ketika Status Relatif $(\mathrm{s})=$ 0,5546

\section{Kesimpulan}

Pada paper ini telah dibahas penurunan model kompetisi antar bahasa pada komunitas monolingual dan bilingual. Kedua model tersebut kemudian dibandingkan 
dengan data empiris penutur bahasa Gaelic di Ross and Cromarty Skotlandia (kasus monolingual) dan bahasa Melayu di Brunei (kasus bilingual). Dari hasil pencocokan model terhadap data, diperoleh nilai-nilai parameter yang cukup kecil yang membuat proporsi penutur bahasa Gaelic dan Melayu menurun secara signifikan dari tahun ke tahun sehingga terancam mengalami kepunahan.

Model kompetisi antar bahasa pada paper ini dapat juga dibandingkan dengan data penutur bahasa daerah yang ada di Indonesia. Dengan demikian dapat diperoleh informasi kuantitatif tentang faktor-faktor yang mempengaruhi perkembangan bahasa tersebut, terutama yang mengalami ancaman kepunahan.

\section{Daftar Pustaka}

[1] Abrams, D. M. , dan Strogatz, S. H. 2003. Modelling the dynamics of language death. Nature. 424:900.

[2] Anonim. 2015. Coefficient of determination. https://en.wikipedia.org/ wiki/Coefficient_of_determination, diakses pada 2 Januari 2016.

[3] Iserles, A. 2009. A First Course in the Numerical Analysis of Differential Equations. Cambridge University Press, Cambridge.

[4] Mira, J. , \& Paredes, A. 2005. Interlinguistic Similarity and Language Death Dynamics. Europhysics Letters. 69:1031-1034.

[5] Panvilov, A. 2004. Qualitative Analysis of Differential Equation. Utrecht University, Utrecht.

[6] Shaby, Ben. 2010. SAMSI UG Workshop: Fitting The SIR Model to Data. http://www.samsi.info/sites/default/files/Shaby_sir_lab.pdf, diakses pada 16 September 2015.

[7] University of Surrey. Tanpa Tahun. Coupled System. www.maths. surrey.ac . uk/explore/vithyaspages/coupled.html, diakses pada 21 April 2015.

[8] Withers, Charles W. J. 1983. A Geography of Language: Gaelic-Speaking in Perthshire, 1698-1879. Transactions of the Institute of British Geographers. 8:125- 142 .

[9] Yanxin L. 2009. Modelling Language Competition. http://guava.physics . uiuc.edu/ nigel/courses/569/Essays_Fall2009/files/liu.pdf, diakses pada 3 April 2015. 